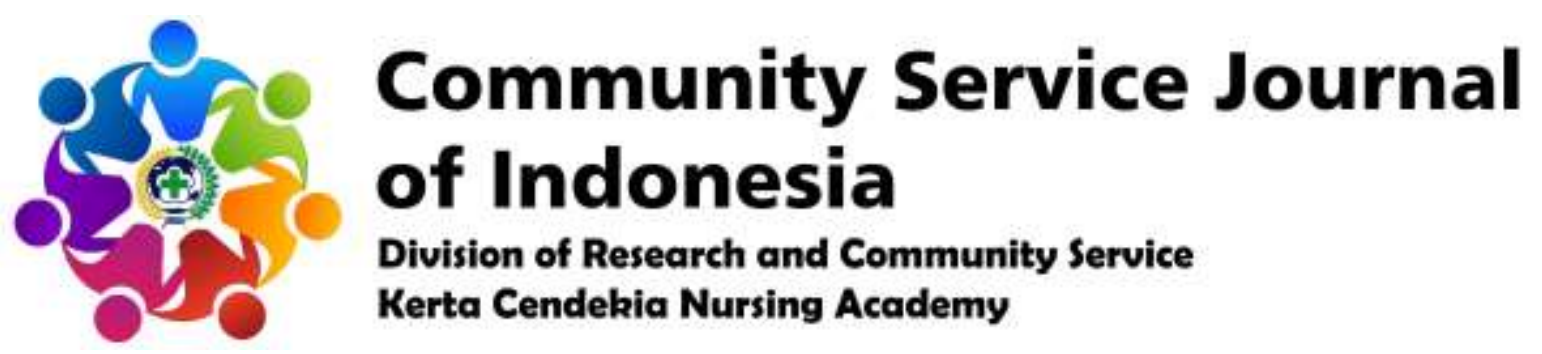

https://ejournal-kertacendekia.id/index.php/csji/index

Community Service Journal of Indonesia 3 (1) (2021): 12-14

Doi: https://doi.org/10.36720/csji.v3i1.287

\title{
THE DEVELOPMENT OF A PLAYGROUND AS AN EFFORT TO REDUCE THE IMPACT OF SMARTPHONE USE ON CHILD'S MINDSET
}

\author{
Vera Rimbawani Sushanty ${ }^{1 *}$, Ananda Liony Putra ${ }^{1}$
}

${ }^{1}$ Faculty of Law, Bhayangkara University, Surabaya, Indonesia

\author{
* Correspondence \\ Vera Rimbawani Sushanty
}

Faculty of Law, Bhayangkara University, Surabaya, Indonesia

A. Yani Road 114, Surabaya City, East Java Province, Indonesia-60231

Email: rimbawani@ubhara.ac.id

\begin{abstract}
Children in this millennial era cannot be separated from the use of smartphones, of course, without parental supervision, it will have an impact on the development of children's mental and psychological conditions. Excessive use of gadgets causes children to do little or even no physical activity at all, such as playing with their friends. Whereas physical activity in children affects the growth and development of children. Therefore, at the Bhayangkara University Surabaya Real Work Lecture, group 062 students took the initiative to make a playground in Tebel Village, Gedangan District, Sidoarjo Regency on 22 May - 6 June 2021. The children and residents around the play area were very happy and excited to come and take advantage of these facilities. It is expected that children are more active and can socialize with their peers.
\end{abstract}

Keywords: The impact of gadgets, playgrounds, physical activity.

(C) 2021 The Authors. Community Service Journal of Indonesia Published by Institute for Research and Community Service, Health Polytechnic of Kerta Cendekia, Sidoarjo

This is an Open Access Article distributed under the terms of the Creative Commons Attribution 4.0 International License which permits unrestricted non-commercial use, distribution, and reproduction in any medium, provided the original work is properly cited.

E-ISSN

2684-7884

P-ISSN

2774-4027

\section{INTRODUCTION}

Excessive use of gadgets in children, especially without parental assistance, has the potential to have a negative impact on children, for example significant changes in behavior, slow motor development, and difficulty in socializing. The age of 1-5 years is a golden age for child development, including the development of spiritual, intellectual and emotional intelligence that 
will determine and influence further growth and development.

The negative impact of using gadgets for child development: 1) It is hard to concentrate on the real world. Addiction to gadgets makes children unable to escape and will be angry if separated from their gadgets. The fun that is obtained makes children tend to be alone and it is difficult to interact with their peers in the real world. 2) PFC function is disturbed. PFC or PreFrontal Cortex is the part in the brain that controls emotions, responsibility, self's control, decision making and other moral values. This function is disrupted if the brain produces excessive dopamine hormone due to children addicted to online games, for example. 3) Introvert. Children think gadgets are everything and of course take up most of their time. Closeness to parents is reduced and children tend to be introverted.

Data showed that when radiation from gadgets enters the head, adults absorb it as much as $25 \%$ of children aged 12 years as much as $50 \%$ and the highest in children aged 5 years, namely $75 \%$. Therefore, the risk of this radiation will be greater in children who are 'familiar' with gadgets at the age of less than 16 years.

One of the efforts to help children's physical activity is by providing facilities that children like. Because playing activities are the most fun activities for children, a playground is made. Play is taking part in fun activities for the sake of entertainment and doing something for pleasure, without persistence.

\section{OBJECTIVES}

General Purpose

After there is a playground, it is hoped that children in Tebel Barat Village, RT 01 RW 01, Gedangan District, Sidoarjo
Regency can use it to do useful activities outside the home.

\section{Special Purpose}

The availability of physical activity facilities is expected to be useful for children in Tebel Barat Village, RT 01 RW 01, Gedangan District, Sidoarjo Regency to play. Because from playing activities, there are benefits for children, including:

1. Playground as a problem solver, where children develop creativity and explore their environment.

2. Play stimulates children's development, both physical, social, emotional and intellectual development.

3. Play strengthens and develops his identity, self-concept and respectability.

4. Play as a means for children to express opinions, values and norms.

\section{PLAN OF ACTION}

Strategy Plan

The plans carried out include:

1. Location survey and permission to the village head.

2. Coordinate with local residents.

3. Playground Construction Proceed.

\section{Implementation}

The implementation of these activities includes:

1. Location survey and permission to the village head.

2. Coordination with the Head of the Neighborhood Association.

3. Preparation of work programs.

4. Play area cleaning and painting.

5. Make chairs and tables from used car tires.

6. Installing a roof for shelter.

7. Installing outdoor toys, including rainbow ladders and basketball hoops. 


\section{Setting}

The activity for making a playground is carried out in Tebel Barat Village, RT 01 RW 01, Gedangan District, Sidoarjo Regency starting on May 22, 2021 until June 6, 2021.

\section{Target}

The target of making this playground is children in the Tebel Barat Village area, Gedangan District, Sidoarjo Regency, especially RT 01 RW 01.

\section{RESULTS AND DISCUSSION}

The activity of making a playground will be carried out starting on May 22, 2021. As a result of the existence of the playground, children are more active in spending their time outside the house by playing with their friends. By playing, children learn to work in teams, behave better, make them happy, increase their learning ability and move more. Residents welcomed and enthusiastic about the existence of this playground. They do not hesitate to help in the process. Parents often accompany their children, especially toddlers to play. Thus, a closeness arises between parents and children, which has a good impact on their mental and psychological development.

\section{CONCLUSION}

With the creation of this playground, it is hoped that children will want to play outside the house, do physical activities, and socialize with their peers. Not only dwelling on the games that are on the gadget. Especially in the golden age of children, the development of spiritual, intellectual and emotional intelligence must be optimized which will determine and influence further growth and development.

\section{REFERENCES}

Muhibbin Syah. (2003). Psikologi Belajar. Jakarta: PT. Rajagrafindo Persada.

Hastuti. (2012). Psikolog Perkembangan Anak. Yogyakarta: Tugu Publisher.

Jonathan,dkk. (2015). Perancangan Board Game Mengenai Bahaya Radiasi Gadget Terhadap Anak. Surabaya: Universitas Kristen Pertra Surabaya.

Ole Fredric Lillemyr. (2009). Taking Play Seriously: Children and Play in Early Childhood Educatioon-an Exciting Challenge. Charlotte, NC: Information Age Publishing Inc 